\title{
Human Right Education as Part of Education for Democracy: the Case of Albania
}

\author{
Gent Sinani \\ gent_sinani@outlook.com
}

\begin{abstract}
With the overthrow of the dictatorial communist regime, in Albania were created opportunities for discussing theoretical - practical human rights. The most typical periods when the man clearly raises and cut the question, "How to live in a dignity?", are periods of great social turmoil. Given this premise, the study embraces some of the most important issues of discussion and the concrete reality of the implementation of human rights in the Albanian reality. Human rights are rights that protect individuals and allow them to live with dignity protected from arbitrary of the state, or any other authority. Human life is an irreversible and therefore human rights constitute a "sacred" space, an unalienable individual sphere. This is why human rights rise to the level of fundamental valuation criteria of democracy and the legitimacy of a government. Given the historical circumstances of the development of democracy in Albania, discussion and attempts to put them in life, should be one of the essential features of education of new generations and youth activity itself. Attracting youth in daily discussion and efforts for the realization of human rights, is an imperative of our democratic life. The study is oriented towards younger generations, especially for the young student as the most emancipated youth, to become a participant in the activity of building a democratic state of law.
\end{abstract}

\section{Introduction}

The starting point of the evolution of an international human rights protection system coincides with the beginnings of frameworks for a permanent cooperation of States. The League of Nations and the International Labor Organization(ILO), both created after the First World War, paved, though modesty, the way for a process to determine human rights and their monitoring. However, only with the foundation of the United Nations in 1945 one may mark the point from where the legal development of human rights and their protection on the universal plane gained a forceful dynamism. Immediately after World War II, in a world filled with millions of deaths and refugees, as a result of racism and the violence of the Nazi-fascist axis, the UN Charter is dedicated "to reaffirm faith in fundamental human rights, in the dignity and worth of the human person, in the equal rights of men and women and of small and large nations" (Preamble). Art. 1 of the Charter is defined as one of the principles of the Organization to promote and encourage "respect for human rights and for fundamental freedoms for all without distinction as to race, sex, language, or religion".

The protection and respect of human rights is the only way for an emancipated society that aims to build a pluralistic democracy. For this purpose, the Parliament of Albania, Council of Ministers and other state institutions with the continued support of the Council of Europe, European Union and other international institutions, have prepared and adopted an entire corpus of normative acts, aiming at the guarantee and protection of human rights.

The basic principles of the protection of human rights and fundamental freedoms are addressed in the Constitution of the Republic of Albania, adopted in 1998. In its Preamble is written: "The Albanian people ... determined to build a rule of law, democratic and social state, to guarantee human rights, fundamental freedoms, with the spirit of religious tolerance and coexistence, committed to the protection of human dignity and personality, the prosperity of the entire nation, with the deep conviction that justice, peace, harmony and cooperation between nations are the superior values of mankind".

In this 25 years Albania have done progress in the field of the education of the Human Rights, especially in the five las years. With the 
Introduction of scholar texts from the primary school where children learn this precious values of the civilized and democratic world. But there is too much to do in this direction, because are needed more professional staff to teach his values. There are also problems in rural areas, if in big cities we can see that children and yang people are more and more aware about their rights and other rights, becoming also more open minded and more aware about democratic values, normally not in a great proportion, it is needed more time for the society to become really reactive for these questions. In the other hand, in the rural areas, even if the scholar texts are the same, the lake of professional staff and the lake of proper attention to these lessons have created a gap between the rural areas and big cities in the consciousness of yang people about human rights and democratic values.

Based on observations done from the office of the High Commissioner of United Nation Human Rights, European Commission Against Racism and Intolerance, Council of Europe National Minorities monitoring, the US Embassy in Tirana reports, we will see some of the major problems in this field in the Albanian society and why the Human Rights education is the crucial and the best way of resolving these problems and to strengthen the democratic values.

\section{Domestic violence}

In Albania and more in particular in rural areas the domestic violence is very common, this happens for many reasons. In the absence of a national authority to monitor and enforce equality in family, as well as in terms of economic difficulties due to the return of private property system of self-employment are also restored habits of the past patriarchal family and in relationships. Early termination of education has increased ignorance in couple's relationships, but also ignorance in recognition of women's rights and protection that the law provides for them. Unemployment, economic dependence of women on men, but also the low level of education are factors that have led to increased domestic violence, not only against woman, but also to children. Albanian society pays less attention to educating men and boys with the values and principles of gender equality, as well with a sense of equality in the family.

Wife works closed in home and have to care about the children, being totally economically dependent on men, without any personality development perspective, while the man holds the responsibility of providing financial income with work outside the home.

Despite legislation, in the private business economy, the women's economic rights are limited. Jobs are low-wage, there are troubles keeping a job for a long time, infractions of the right to break in case of illness or to care for a child, infractions of the right to paid holydays, there are sexual harassment and exploitation of the difficult economic situation to seek from woman sexual favors, etc. Even the movements for the rights of women are very weak, if not inexistent. They appear only temporarily, with some political orientation, for a sensitizing activity.

\section{Societal Abuses, Discrimination, and Acts of Violence Based on Sexual Orientation and Gender Identity}

The law prohibits discrimination against lesbian, gay, bisexual, and transgender (LGBT) individuals. Despite formal law and government support for LGBT rights, it continues to appear homophobic attitudes in the Albanian society.

Albanian society comes from a long period of isolation and in the past it was cultivated with socialist morality against sexual orientation and gender identity. Gender identity is based completely on two opposite sexes, female and male. Deviant sexual orientation was only accepted due to physical disorders from birth, and these people were considered unhealthy.

With the transition to democracy, Albanian society found itself unprepared to accept and understand a variety of sexual behaviors or gender identities. To this is added the fact that Albanians were returned with rashly to the religions stopped during the socialism. Religious institutions and religious morality have always been against the diversity of gender identities and sexual diversity. So, despite the major influences from contemporary European culture, that came through all the changes in the education system, these social aspects have created the same barriers that previously created the socialist system in matters of sexuality.

Albania is considered one of the most homophobic countries in Europe and according to different surveys in Albania more than $53 \%$ of peoples are against homosexual people. However, the fact that nearly half of the population is indifferent to 
sexual identity or sexual behavior of others, demonstrates a considerable level of openness of social awareness, considering such issues as matters that regards to individual free choice and accepting them such as.

\section{Minorities}

Roma in Albania were the big losers of the economic and political changes of 1989-1990. Being undereducated and unskilled, their position in the society changed drastically, while being fully employed during communism, their participation in the mainstream economy diminished to a quasi-total unemployment after 1990. As a result of that, the new generations of Romani children are unable to go to school due to the inability of their families to afford their children's education, with only a small number of individual exceptions. The economic situation of the Roma in Albania is very poor and the rate of unemployment is several times higher than that of the non Roma. The housing conditions are very bad. The poverty of the Roma vis-à-vis the majority of other minorities in Albania is higher.

Romani and Balkan-Egyptians faced discrimination in access to housing, employment, health care, and education. Some schools resisted accepting Romani and Balkan-Egyptian students, particularly if they appeared to be poor. Local NGO-s reported that many schools that accepted Romani students marginalized them in the classroom, sometimes by physically setting them apart from other students.

Generally, teachers complain about the lack of care from Roma parents to their children. Roma pupils sit in the last rows in the classrooms, as students refuse to sit with them, either because of personal hygiene conditions, either because of their lack of discipline in the classroom. The Roma community has been the victim of child trafficking, sexual abuse of minors, marriages of underage girls and women trafficking. The Special Rapporteur on the sale of children highlighted the fact that Roma and Egyptian communities are discriminated against in all spheres of life and the accumulation of disadvantages results in multiple forms of exclusion and marginalization.

\section{Children rights problems}

Despite the Albanian government efforts, there is needed to much work to do in this important field of the human rights. In general, poor families that don't send children to school but send them in work. In practice many children left school earlier than the law allows, in order to work with their families, particularly in rural areas. Parents must purchase supplies, books, uniforms, and space heaters for some classrooms, which were prohibitively expensive for many families, particularly Romani and other minorities. Many families also cited these costs as a reason for not sending girls to school. Although the government has a program to provide free textbooks for low income families, many families and NGOs reported that they were unable to acquire the free textbooks.

Another problem is the child abuse, including sexual abuse, occurred, although victims rarely reported it. The minimum age for marriage is 18. Underage marriages occurred mostly in rural areas. According to UNICEF statistics, 10 percent of women were married or in union before they were 18 years of age. Some NGOs have reported that child marriages occurred in rural communities as part of human trafficking schemes, when parents consent for their underage girls to marry older foreign men, who subsequently trafficked them to other countries.

\section{State of Law}

One of the biggest problems for societies that have been part of the dictatorial system and now are in democratic systems but with economic problems is the creation of the State of Law. This is a real challenge for these countries and their society. Albania as a country that have had a dictatorial regime even after 25 years continue to have big problems with the State of Law. Reports from US Department of State, UN and EU institutions talk for problems in the judiciary system, for high corruption in all the public administration level. All these years in transition have created the so called "the culture of impunity", no matter what you do, if you can corrupt the judge you can be free.

The lake of the political will to change this system appeared even these years with the justice reform, that regardless the international pressure the political party haven't found a common language yet, and no one now when it will happen. 
In the Albanian society there are too many problems in the field of employments rights to. The working conditions are not respected; they are respected only in big companies that have the headquarters in capital city or in the other Albanian big cities. This situation is created because, even if the right to be organized in order to defend your rights exists, the Albanian society continue to have a lack in the gathering of employs to demand the respect of laws from employers. There are a low level of syndicates and their field of action is very limited do to the absence of experience in the society in this direction.

Another problem of the Albanian society in rural areas is the legacy of the Kanun (customary law) also called the law of blood. As mentioned before the lack of education in rural areas, and the lack of the education of human rights in that areas were education is possible have created a gap that is filled from this customary law, that from the constructional law are interdicted. During the dictatorial system the Kanun was interdicted by the force and the fear, immediately after the change of system, the state was weak and the customary law immediately returned in rural areas. The other countries our past experience have demonstrated that without the adequate education of the population this laws will continue to exist.

The constitution provides for freedom of speech and press, and the government generally respected these rights in practice. However, there were reports that the government and businesses influenced and pressured the media. The independent media are active and largely unrestrained, although there are cases of direct and indirect political and economic pressure on the media, including threats against journalists. But sometimes political pressure and lack of funding constrained the independent media, and journalists to practice self-censorship. In its annual Media Sustainability Index, the nongovernmental organization IREX have noted that the independence of the media in the country have decreased, and more media outlets had fallen under the direct influence of political parties.

Business owners also freely used media outlets to gain favor and promote their interests with both major parties. Many media owners courted government leaders to gain favors or avoid taxes. There have been incidents of violence against members of the broadcast media, and journalists were subjected to pressure from political and business actors. Journalists continued to complain that publishers and editors censored their work directly and indirectly in response to political and commercial pressures. Many journalists complained that a lack of employment contracts frequently hindered their ability to report objectively and encouraged them to practice self-censorship.

Another big problem the last years is the increase in verbal threat, in speeches and public discussions against the media and journalists from politicians. Free expression or "criticism" is reduced to what the political parties participating in the game allow, in other words there are critical issues to which the parties themselves agree to allow criticizing. Such a situation can be described as "freedom of expression with the mouth closed".

The way the press and media works today, the way how they strategies are built, assistance in this area or monitoring, have created the feeling that freedom of expression is a franchise of journalists, publishers and the media, and not a right of everyone, which should exercise all freely and everyone should have access to the debate in the press as well as visual media.

\section{Conclusions}

Albania is one of the European countries that inherited a complicated history because of the implication of the interests among the great powers and, on the other hand, a small country that was isolated under proletarian dictatorship during the Cold War. The destruction of private property to create joint property during socialism, left the individuals very poor.

When the socialist system was overthrown and private relationship came in first plan, individuals drawn from the property were unable to build an independent economy. The division of community property was carried out by corruption. The abusive resolving of the issue of property and the delay of many issue through endless trials juridical process, has greatly disadvantaged the free initiative, breathing of the economy and restrain investments the Albanians investment and from foreigners, due to insecurity. An extraordinary number of people, especially the ones that had higher education, was forced to emigrate abroad to ensure the subsistence minimum, which could not provide in Albania.

These massive population shifts have created a big gap and was followed by other domestic shift that brought significant structural changes of the population of cities and changes in the urbanization processes especially in political life. 
Albanian society that have emerged from the dictatorship of the proletariat, has hardly conceive individual freedom as a value of personal freedom, despite general national freedom. Socialism educated freedom as a collective value. Individual freedom was seen subdued and in view of the general freedom, and it did not make sense without total freedom, ore out of total freedom. Individual freedom has value only to the extent that serves national freedom. Building a democratic society cannot be performed without his soul - free man- free individual. The protection of freedoms and human rights is at the fundament of the constitutional order, but building democracy requires education of these values of individual freedom and human rights. Educational system should turn entirely on individual freedoms and rights. And here, philosophers and jurists have and should play their very important role.

"A nation" - Tocqueville wrote referring to the American example - "who has never heard to be treated before it the state issues, believes the first tribune that appear to him". This opinion, in the form of a maxim, has great value for citizens to be careful in what they choose, because at the time of democracy as Tocqueville says "charlatans of every kind can benefit, while often true friends of the people fail" (Tocqueville, A., 1981: 268. 286)

In any case, the starting point in a democratic society is the individual and respect of his fundamental rights. Society, political organization and power are only tools that aimed at the full realization of human rights, and respect for his dignity.

In the Federalist Papers, Publiusi, sees the problem of popular representative government in three plans. "Firstly, it is possible that people lose control of his government and that governors choose to trick with the regime. Secondly, there is the possibility that the majority of the people, through representatives flattering, bring into force the oppressive government. Thirdly, there is the possibility that the majority, through their representatives, to govern in the wrong way, ore, to take the wrong way".

In a republic without separation of powers, where all powers are concentrating in only one body, there didn't exist "protective barrier" against authoritarianism and corruption. Separation of the power into three independent spheres that act only in accordance with the constitution is the only way for a country to be a democratic state. This is the lesson that comes from the theory. Practical solution is a problem that belongs to a nation's legislators to concretely embodied and political class to implement it. In Albania, this issue has remained in the sphere of political rhetoric.

Freedom of speech associated with freedom of the press, not only expresses the real spaces of democracy, but also serves to the society to preserve the democracy. Freedom of speech and of the press allow the criticism of the political class and the request for explanation, exerting pressure on the political class to avoid violating promises and programs for what they have received the votes - at least so it is, or should be theoretically. The freedom of the press is that force that puts in front of the public opinion the ideas of politicians, in order to be subordinated to their judgment. But if society is not sufficiently educated to the freedoms and human rights, it is impossible for here to judge the policies.

But there is also the danger that the media from a very useful element of democracy to be reversed, in erase of the free speech and the criticism of the political class, when it is subject to political pressures, this is why is always needed a society that is very good educated with values of democracy, always vigilant for his rights and freedoms, to be able to react with the minor infringement of these rights. To be able to caught the cheating that is done to the public and the mediocrity, is needed a public capable to doubt and ask questions about ideas and policy discussions.

Equality love drives people to seek goods that he cannot possess, because to them is born the hope that they can reach these goods, but the competition is at a such level that every person has little chance to realize their ambitions. Moreover, the way to satisfy these desires is not an equitable way. In search of a solution to satisfy his desire, man abandons freedom. It is exactly the abandon of this freedom from men, observed Tocqueville, which could lead to the emergence of a despot, as it is known of past epochs. This situation of abandonment of freedom Rousseau has expressed it in these words: "Freedom is a very juicy food, but needs a strong digestion; are needed very healthy stomachs to handle it... Holy and proud freedom! If these desolated people could recognize you, if they would know how your laws are much stronger than it is the wild violence of tyrants, their poor spirits, slaves of passions that must be crushed, will fear here hundred times more than slavery; they will leave here with horror, as a burden ready to throw". 
Minimizing these risks that come from inside the individual can be achieved by cultivating a culture of work, and this is done through education, but an education that enables the individual and makes him be free in his life, because man can be free only when he is knowledgeable.

Tocqueville also praised democracy because it inspired people non-obedience, this instinctive tendency for political independence. Education in democracy and human rights constitutes the imperative of time new generations and, in the other hand, youth participation in political life is a necessity to limit the politics of surfing towards authoritarianism. As a direct product of society, democracy depends very much on the cultural level of the society.

A society filled with individuals who buy degrees, affects too much in issuing not capable leaders in knowledge, but more skilled in "ignorance". Rather a healthy educated society develops a healthy democracy, where freedom and equality go near each other. Properly Sorokin, from 1920, wrote by having in consideration the establishment of Bolshevik regime in Russia: "There is no need to prove the simple truth that many people forget, that the perfection of social organization, the prosperity and creativity in various fields of society, its historical performance and fortunes depend, first of all from the nature of its the members. For the evilly ones we can write an ideal constitution, however it will remain on paper. While a society, composed of innocent angels, may have a very bad constitution or not at all, and yet the social relations among its members can be wonderful. A society composed of villain or stupid, in all the reforms that can undertake will make fraud and will remain spiritually desolate as far as its members shall possess such qualities" (Pitirim Sorokin).

\section{Bibliography}

http://www. coe. int/en/web/minorities/country-specific-monitoring\#Albania

http://www. ohchr. org/EN/Countries/ENACARegion/Pages/ALIndex. aspx

http://www. coe. int/t/dghl/monitoring/ecri/library/publications. asp

http://tirana. usembassy. gov/key_reports. html

Alexander Hamilton, James Madison, John Jay: "Letrat e Federalistit", Produced by, USIA Regional Program Office, Vienna.

Jean Jacques Rousseau: "Du Contrat Social et autres oeuvres politiques”, Paris, 1975, Édition Garnier Freres.

Albanian Free Forum: "Deputeti dhe Elektorati", Tirana, 2007, Mediaprint.

Foundation for Conflict Resolution and Reconciliation of disputes: "Pajtimi", Tirana, 2000.

Albanian Center for Documentation of Human Rights: "Revista Shqiptare për të Drejtat e Njeriut", Tirana, 1995, Grafika ARS.

Fridrich Ebert Stiftung-Office Macedonia: "Political Parties and Minority Participation”, Skopje, 2008.

Albanian Institute for International Studies: "Twenty Years After: People on State and Democraty", Tirana, 2010. 